JOURNAL OF SECURITY AND SUSTAINABILITY ISSUES

ISSN 2029-7017 print/ISSN 2029-7025 online

2020 June Volume 9 Number 4

http://doi.org/10.9770/jssi.2020.9.4(19)

Scopus

\title{
MANAGEMENT OF THE POLICE OFFICERS TRAINING SYSTEM AND THE EFFECTIVENESS OF INTERNAL SECURITY
}

\author{
Marlena Lorek $^{1}$, Teresa Piecuch ${ }^{2}$, Jolanta Itrich-Drabarek ${ }^{3}$, Mirosław Minkina ${ }^{4}$ \\ ${ }^{1,2}$ Rzeszów University of Technology, Aleja Powstańców Warszawy 12, 35-959 Rzeszów, Poland \\ ${ }^{3}$ University of Warsaw, Krakowskie Przedmieście 26/28, 00-927 Warszawa, Poland \\ ${ }^{4}$ University of Natural Sciences and Humanities in Siedlce, Stanistawa Konarskiego 2, 08-110 Siedlce, Poland

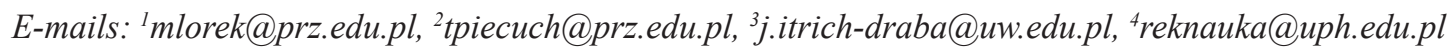

Received 18 November 2019; accepted 19 April 2020; published 30 June 2020

\begin{abstract}
Employee training is a systematic activity implemented in a hierarchical organization to which the police belong. It is therefore necessary to properly manage this system at the appropriate level, because it has a positive impact on the level of social security. Staff training and development are increasingly appreciated by organizations, especially those that implement a country's security policy. The purpose of the study is to present the essence of training and improving Police employees, which in turn will allow to develop a model for such training and its management as one of the most important tasks of the personnel departments. Management in this area plays an important role in setting directions for the development of employees' potential and effectively facilitates the introduction of any changes that will be reflected in the work effectively performed by officers.
\end{abstract}

Keywords: internal security; management; police; training policy; ethics

Reference to this paper should be made as follows: Lorek, M., Piecuch, T., Itrich-Drabarek, J., Minkina, M. 2020. Management of the police officers training system and the effectiveness of internal security, Journal of Security and Sustainability Issues, 9(4), $1337-1348$. http://doi.org/10.9770/jssi.2020.9.4(19)

JEL Classifications: H53, M53

Additional disciplines: political sciences and administration.

\section{Introduction}

As indicated in the scientific literature, ,the concept of capital refers to the permanent determinants of the selection and implementation of human activities. Capital is most often the product of previous activity, affecting the course of current activity. [...] Every capital is always created from scarcity (,scarce inputs”) and is therefore in itself a kind of deficiency and the subject of entropy „(Bańka 2006).

The beginning of the 21 st century is the primacy of human capital. "Human capital is a resource of knowledge, skills, health and vital energy, contained in every person and in society as a whole, defining the ability to work, adapt to changes in the environment and create new solutions"(Domański 1993). The quality of the organization's staff translates into the effectiveness of its operation.

The main purpose of this article is to show how important training for police officers is and whether raising professional qualifications increases quality during the performance of their professional duties. The object of research is the analysis of documentation prepared on the subject of training centers for the Polish Police as well as the training offer, which in turn is expected to affect the level of effective involvement of officers 
in professional work. The main research problem is determining which trainings raise the competences of officers the most and whether trainings really have an impact on their involvement in professional work. In order to conduct research, the method used is the analysis of compact documentation on training in the Polish Police.

\section{Training - definitions, types}

Training is a set of elements that affects intentional activities in an organization. Each organization strives to develop human capital, which allows it to acquire competences that will be necessary now or in the future for all employees of the entity (Mishchuk et al., 2016; Pocztowski 2003; Bilan et al., 2020; Laužikas, Miliūte 2020, Bombiak 2020; Adeniran et al., 2020).

The knowledge we receive during the training is also a form of activity that is created in the organization, so that employees can better fulfill their duties (Bramley 2001). Training also means a continuous process of improving employees' qualifications, knowledge and skills. The acquired knowledge should be well grounded, which will allow its use during any problem in the organization. Employee development is always based on innovation, acquisition of value and culture, which allows the extension of own intellectual competences (Zbiegień-Maciąg 1996). Organizations therefore want the training offer to be effective. This is due to the assumption that training is a process of raising the level of skills and professional development of employees, which contributes to the achievement of the organization's goals.

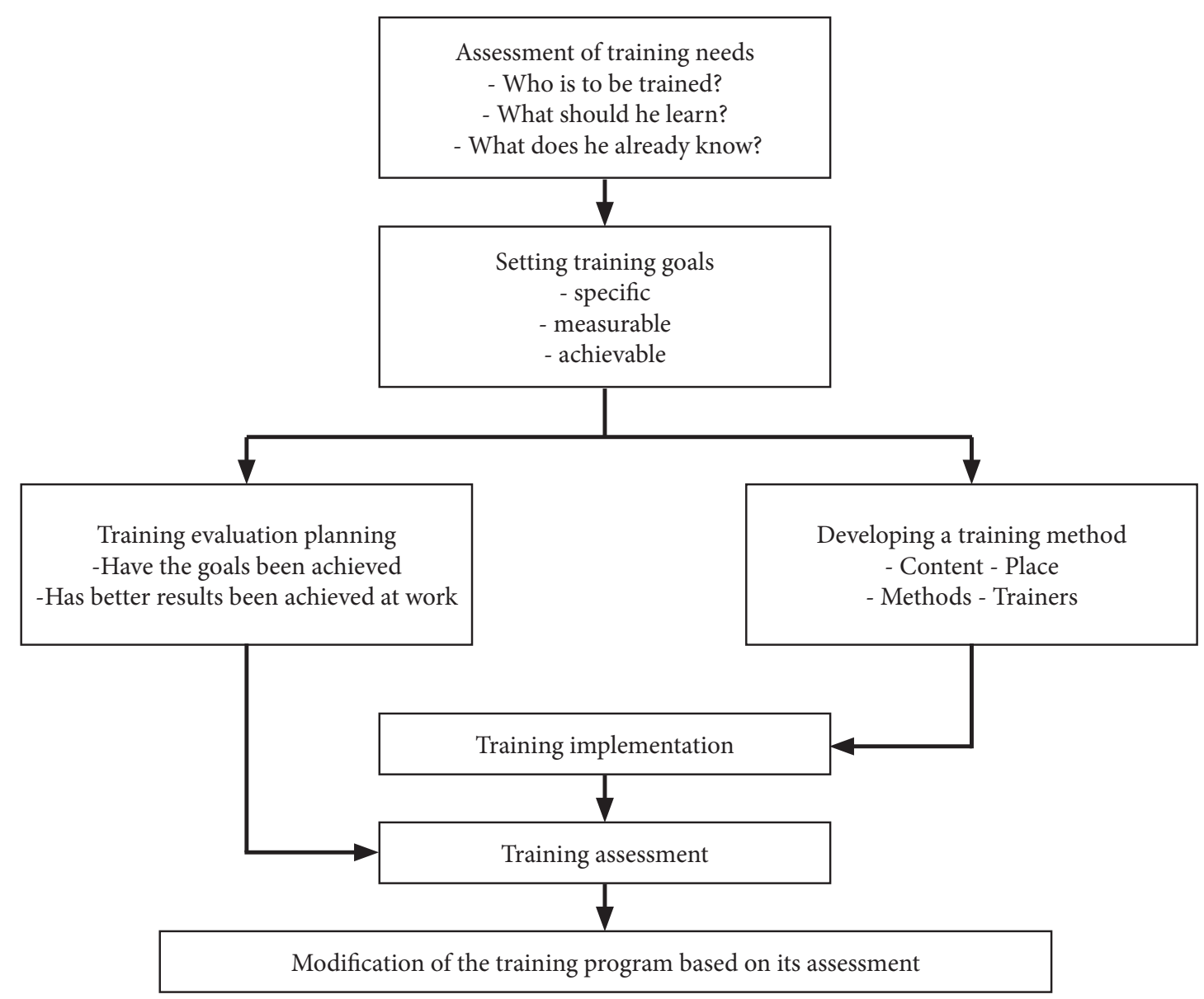

Figure 1. Elements of the employee training system 
The training organization process is the most important from the point of view of the effectiveness of the training system being implemented, because proper diagnosis of training needs will allow selection of the appropriate method and type of training (see Figure 1 above). Professionally selected training should be analyzed at the appropriate levels. The most important of them include: organization of the position in which the training is organized, and selection of employees (Lorek 2017). The results achieved during the training should be supplemented at various levels so that there are no gaps in the selection of training. Assessment of training effectiveness is a very important element in the training process, as it should be organized during and after the course cycle. Therefore, medium or long-term assessment in the workplace is necessary to determine whether the objectives set for the training have actually been achieved and what benefits the company investing in the training has achieved (Rae 1999).

Depending on the training objectives, they can be divided into three types (Kostera, Kownacki 1996):

- preparatory and introductory training for work - passes professional knowledge, skills and behavior to recruited employees,

- adaptation training - expands existing knowledge, skills and employee attitudes for the needs of the new job requirements,

- change training - to change professional qualifications; here the employee receives a new profession or specialization.

The division of trainings by time allows to distinguish trainings: evening, weekend, one-day, several-day, more than a week.

The division of trainings by form separates: the course (most often about 20 people participate in it; the teacher wants to provide participants with knowledge based on the selection of appropriate methods), seminar (about 30-40 students participate in this form of classes; all of them share their experiences and the teacher is only the organizer), workshop (16 people participate in it; all participants develop some material under the tutor's guidance), conference (meeting of specialists who share experiences - 50-100 people).

Open training takes place when recruitment is not restricted and many people can participate (Tyborowska 2006). Closed trainings are organized for selected participants. Participants must be invited to attend. Soft trainings are addressed to both managerial staff and lower-level employees. The main purpose of these exercises is to enrich team management skills. Whereas managers and senior management want to learn the secrets of personnel management. At this level, supervisors should focus on the process of motivating their subordinates to work. The task of these trainings is either to solve a specific problem that has arisen in a given company or to improve the skills of employees on whom the employer is particularly concerned. Hard training is knowledge training. This training does not focus on developing interpersonal skills. Participants in this type of course are on site at their workplace because they are usually organized at the workplace or at the company that organizes the training.

(see Figure 2 above) shows a general human resource development model in which the development strategy is an integral part of the enterprise strategy. The human resources development strategy defines the improvement of individual elements of this resource. The development process is constantly modified by comparing the desired and existing structure of human resources. It can be seen that the development contains elements established at the beginning of the strategy, as well as changes occurring during the implementation of strategic tasks (Pocztowski 2008). 


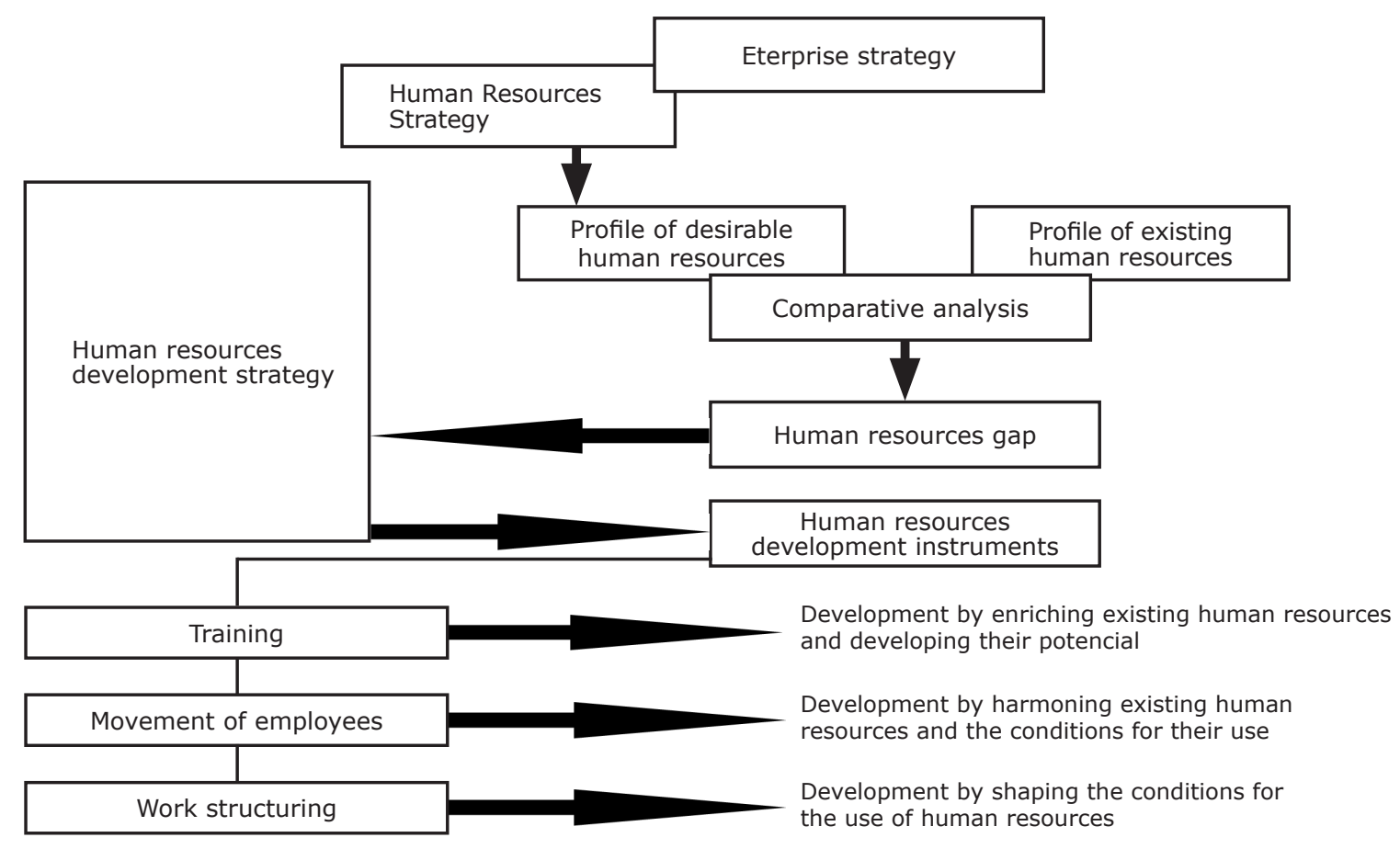

Figure 2. Model of human resources development

Source: Pocztowski 2008.

In general, the training need is the area of employee competence requiring change or modification through training. Identifying training needs is to gather information necessary to determine real training needs. Taking into account their subject, they can have the character of current, adaptive and developmental needs (Król, Ludwiczyński 2007). In some cases training conducts via using knowledge management systems (Mishchuk et al., 2016). Its results are especially positive if they have links with human capital development estimation and remuneration (Bilan et al., 2017).

Identifying needs is also determining the gap in individual employee competences. This is very important because we can predict the future market requirements for staff competencies. In the era of technological progress and market development, we need to constantly supplement our knowledge and experience, because thanks to such efforts we will be competitive on the market. However, it is worth asking yourself who really needs education in the organizational unit, as this will allow you to quickly find and eliminate unnecessary training. The right form of training will meet the needs of both staff and supervisors (Ścibiorek 2010).

Current needs arise when an urgent situation disturbs the proper course of the system's operation, which requires relatively quick training activities. Adjustment needs occur when the training enables employees to perform additional tasks in a given workplace. Development needs are carried out with a view to future vertical or horizontal staff movements. The most popular method of identifying training needs is effective management of employees' competence portfolio and the entire system. Its correct and reliable application is synonymous with the consistency of training needs with the adopted general and personnel strategy of the enterprise as well as its organizational and training culture, as well as the proper determination of training needs both in terms of the holistic work system and in relation to individual employees (Szałkowski et al. 1996). The study of training needs includes determining the target group of training, i.e. people who are to participate in it. It is important to discuss what to do first: identify training needs or define a target group. Both of these activities are intertwined with each other. As a result, a proper examination of training needs should give an answer to which employees should be trained, and at a later stage also make it possible to determine what their personal expectations regarding future education are. 


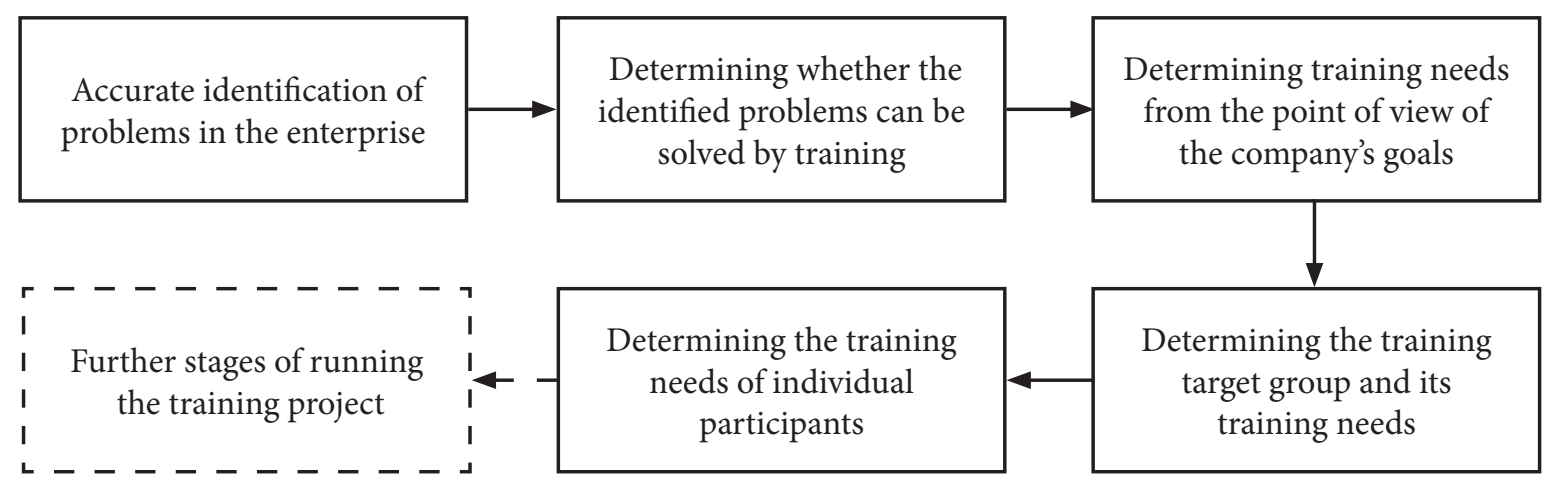

Figure 3. Order of proceedings

Source: Bramley 2001.

When designing the training program and selecting the methodology, knowledge about the stages of human learning is necessary. Without knowledge of this process, it will be difficult to construct a suitable program and choose the methodology used (case studies, games, role plays, etc.; (see Figure 3 above), where order of proceedings is presented). Of course, this knowledge should be acquired primarily by a trainer, but it will also facilitate the work of the training project manager. In practice, it is possible to distinguish four main stages that reduce knowledge not only to the information possessed by the participant after the training, but also to the ability to use it and the acquired attitudes and learned behaviors. Everything is done according to the diagram in (see Figure 4 above).

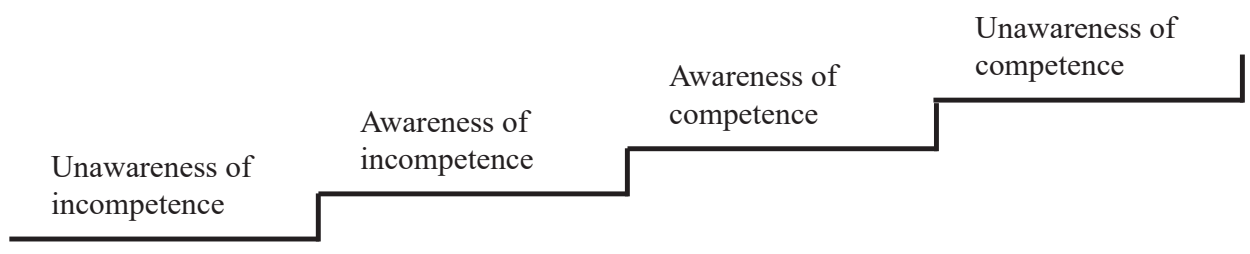

Figure 4. Ladder of competences

Source: Rae 1999.

The special type of organization that will be analyzed in this study is the Police.

\section{Police training system and the effectiveness of its officers in the field of internal security}

The Ordinance of the Minister of the Interior and Administration of 19 June 2007 on detailed conditions for vocational training and professional development in the Police sets out the types of vocational training and professional development, forms, conditions and mode of their completion, as well as the organization and manner of conducting training and supervision over their implementation. Currently, the only compulsory training in the Police is basic vocational training. In addition, there is a guided self-education system in which, in particularly justified cases, training can be conducted with the consent of the Chief Police Commander.

Basic vocational training is conducted according to a uniform program preparing police officers to perform official tasks in positions requiring basic vocational qualifications. It applies to all newly admitted policemen irrespective of education, but the ordinance does not indicate the duration of this training or the division into stages. For policemen in the candidate service basic training is conducted in the field of preparation for administrative and orderly activities, while for policemen who have completed the candidate's service basic vocational training is carried out in the scope complementing the differences between the training they received in OPP and basic vocational training (for newly admitted policemen). 
The regulation also introduces an additional provision informing that a police officer after the candidate's service is directed to this training no later than within 4 months from the date of his admission to service. If the interval between the end of the candidate's service and admission to the service is more than a year, the police officer must undergo all basic vocational training. There is no longer any qualification upgrading of compulsory specialist trainings, although the name itself (probably misleading) has remained and specifies training in the framework of vocational training implemented centrally.

Vocational training for university graduates is conducted for police officers in permanent service according to a uniform program preparing them for performing official tasks in positions where higher professional qualifications are required. A police officer who meets all of the following conditions may be referred to such training:

- has higher education with a master's degree or another equivalent degree,

- submitted a written report on this matter,

- he is provided with an official post immediately after the end of the training, in which higher professional qualifications are required, or he is serving in an official post for which a police full-time rank in the corps of Police officers has been determined,

- at the latest on the day of completing the training, he / she will meet the requirement in the field of service experience, on which the appointment or appointment to an official position depends.

A six-grade scale of grades is maintained at all trainings. However, if it results from the training program or requires it by the nature of the knowledge or skills taught, a two-level grading scale with a generalized 'passed' or 'failed' entry can be used to assess the degree of knowledge acquisition or mastery. The regulation also regulates the deadlines for passing credits and examinations. Corrective credit is made within 2-7 days from the date of the first credit, but at the student's request a time limit shorter than 2 days may be set.

Activities in the field of training and professional development of policemen are implemented on the basis of many legal acts, of which the most important are:

- the Act of April 6, 1990 on the Police,

- regulation of the Minister of the Interior and Administration of 19 June 2007 on detailed conditions for vocational training and professional development in the Police,

- order No. 1041 KGP of 28 September 2007 on the detailed principles of organization and scope of operation of police commands, commissariats and other organizational units of the Police,

- decision No. 863 KGP of december 5, 2007 on the development, introduction, amendment and repeal of vocational training programs and curricula,

- decision No. 48 KGP of 17 February 2011 on the list of specialized course programs constituting training programs.

In the light of national law, the police training system has two levels and includes:

- basic vocational training,

- vocational training for university graduates.

The classic forms of raising an officer's professional qualifications are:

- basic training,

- training to expand officers' knowledge and skills,

- planning individual or group careers,

- desire for professional development through numerous trainings,

- increasing the potential of knowledge during professional development,

- positive impact of training to greater motivation of the entrusted goals (Jurgilewicz 2017). 
The (see Figure 5 above) below shows the applicable system of police training and professional development.

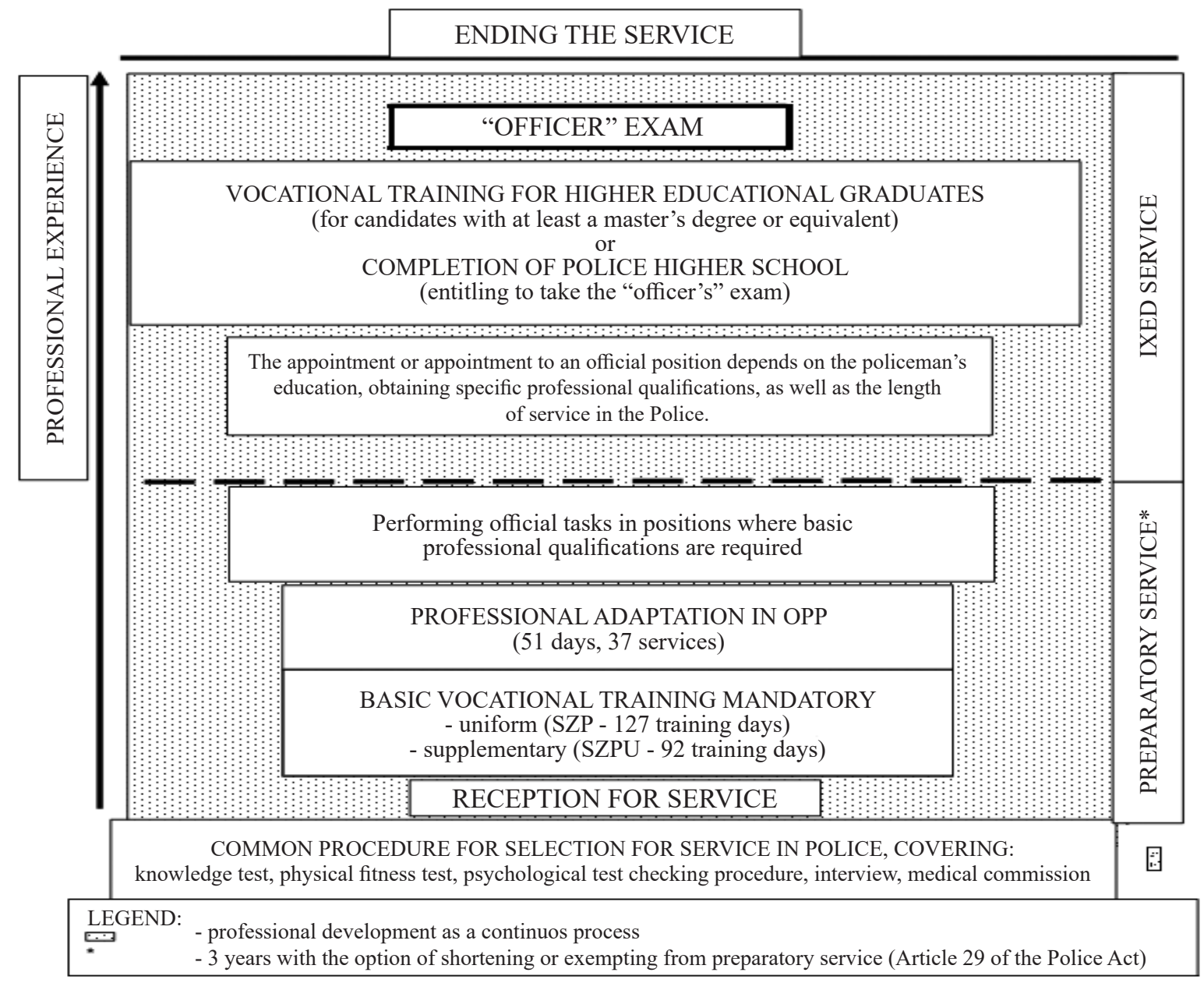

Figure 5. Model of vocational education in the Police

Source: http://www.policja.pl/ftp/pliki/strategia_szkolnictwa_policyjnego_na_lata_2007-2009.pdf

The principles of organizing the Police and the scope of activities of Police organizational units and units, including those relevant to training matters, regulate:

- the Act of April 6, 1990 on the Police,,

- Order No. 1041 KGP of September 28, 2007 on the detailed principles of organization and scope of operation of police commands, commissariats and other organizational units.

Tasks in the area of training and professional development are implemented by: the Police Headquarters, Police College in Szczytno, police schools and provincial (capital) Police headquarters and their subordinate units and organizational units, including the Police Training Center in Łódź.

The (see Figure 6 above) shows the location of training units in Poland, including five Police Schools and one training center in Łódź. 


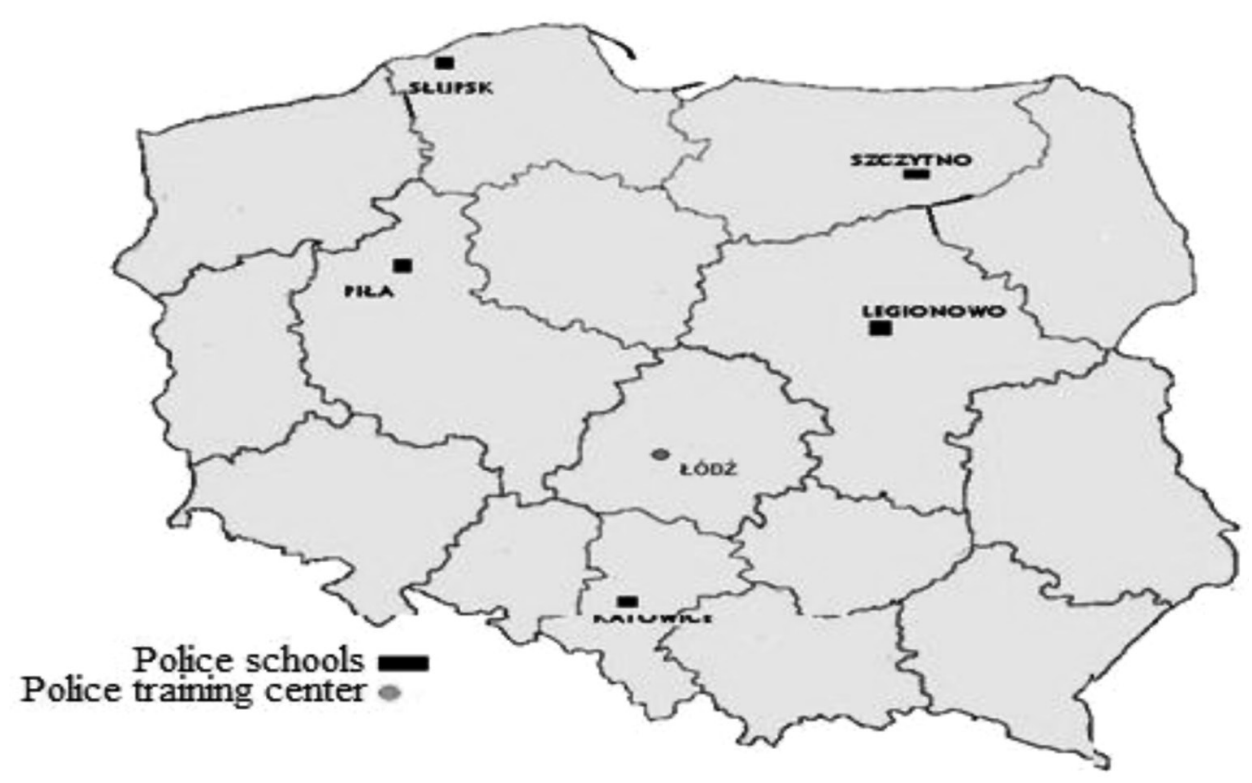

Figure 6. Location of Police training units

Source: own study.

The concept of training effectiveness can be defined as the systemic gathering of information and formulation of a value judgment about all elements of the officers' training system. The funds allocated to training officers constitute an investment for the Police and, more broadly, the entire state. The purpose of training effectiveness evaluation is to obtain information on whether the training has delivered the previously anticipated results. First of all, you should check whether it has brought benefits. The assessment is done by gathering information on the results of the training and comparing them with the goals that were set before the training. This allows you to identify program weaknesses. In this context, assessing the effectiveness of training is very important because it allows you to state:

- what is the effectiveness of the examined program in achieving the set goals,

- to what extent did he meet the expectations of the police and officers,

- did officers expand their qualification potential,

- whether the transfer of new knowledge was carried out and whether as a result of this transfer the expected changes took place, which subsequently had a positive impact on the effectiveness of police resources management,

- whether the training program has met its goals,

- detecting strengths and weaknesses of the training,

- has the appropriate program, content, methods been selected,

- whether the training successfully met the expectations and needs of the participants,

- which training participants benefited most or least from the training program.

The need for training is beyond doubt. The legitimacy of investing in this sphere is appreciated both by those who decide to allocate considerable funds for such a purpose, as well as those who undergo training processes. In order to take full advantage of the opportunities and opportunities arising from it, it should be remembered that the training and training of officers is a process that must consist of effectively functioning subsystems, none of these elements can be underestimated. Training goals and needs should be clearly defined so as not to miss the possibility of assessing the effectiveness of these activities (which should confirm their sense) and the assessment must take into account the largest possible spectrum of impacts at all levels of benefit. Policemen who have completed the candidate's service have the opportunity to undergo basic vocational training to complement the curriculum differences between their previous training in the candidate service and uniform (full) 
basic training, but due to the professionalization of the armed forces, in particular in connection with suspension from On January 1, 2009, the duty to undergo basic military service, on March 9, 2011, the last edition of the training in question ended.

Table 1. Types of basic vocational training

\begin{tabular}{|l|l|c|}
\hline \multicolumn{1}{|c|}{ Name of the training } & \multicolumn{1}{c|}{$\begin{array}{c}\text { Duration } \\
\text { (training } \\
\text { days) }\end{array}$} \\
\hline Basic vocational training (SZP) & $\begin{array}{l}\text { Decision No. 821 KGP from November 19, 2007 } \\
\text { Amendment: Decision No. 9 KGP of January 11, 2010 } \\
\text { Amendment: Decision No. 347 KGP } \\
\text { November 5, 2012 }\end{array}$ & $\begin{array}{c}124 \\
\text { Decision No. 348 KGP from November 22, } 2010 \\
\text { Amendment: Decision No. 224 KGP of June 27, } 2011 .\end{array}$ \\
\hline $\begin{array}{l}\text { Basic vocational training for policemen, graduates of selected } \\
\text { fields of study and people who pass a knowledge test covering } \\
\text { the content of education selected from the vocational training of } \\
\text { policemen (SZPU) }\end{array}$ & $\begin{array}{l}\text { Amic vocational training for policemen who have completed the } \\
\text { candidate service (SZPPK) }\end{array}$ & $\begin{array}{l}\text { Decision No. 17 KGP of 11 January 2008 } \\
77\end{array}$ \\
\hline
\end{tabular}

Source: own study.

Basic vocational training (see Table 1 above) can be provided by all Police training units (except for SZPU training, which cannot be implemented by the TSO in Łódź).

At the same time, regionalization, i.e. the allocation of garrisons to training units, is a major threat to the proper planning of the implementation of basic vocational training. Although basic vocational training is carried out by all Police training units, their limited training capabilities, uneven distribution across Poland and the size of individual garrisons mean that police are directed to undergo basic training to remote training units. In particular, this applies to the southern garrisons, within which only one training unit is located - SP in Katowice, currently with 740 training places. The most optimal training options are shown in the (see Figure 7 above).

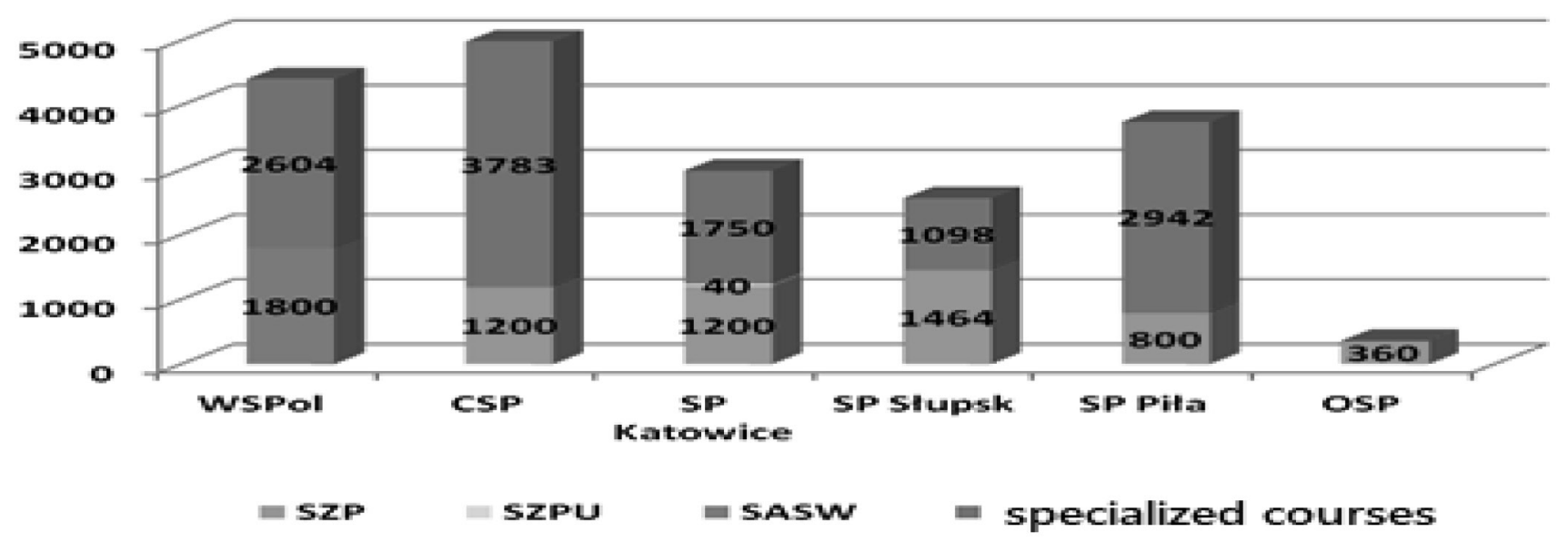

Figure 7. Optimal training opportunities

Source: own study.

The (see Figure 7 above) below shows the maximum training needs. The maximum possibilities indicated by the training units will allow to obtain the following number of graduates per year:

- basic vocational training (SZP) - 7607,

- basic vocational training for policemen, graduates of selected fields of study and people who pass a knowl- 
edge test covering the content of education selected from the vocational training of policemen (SZPU) - 368,

- vocational training for university graduates (SASW) - 1800,

- specialized courses - 15966.

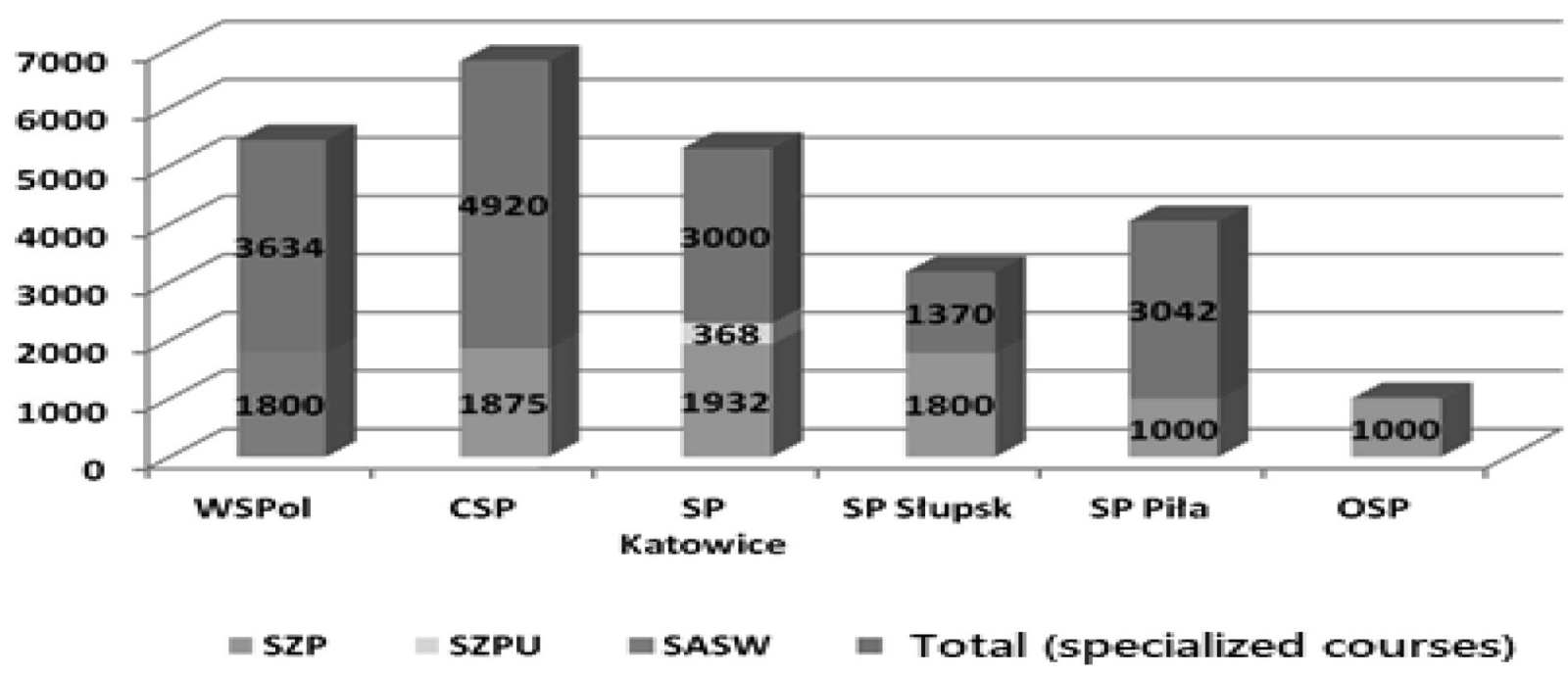

Figure 8. Maximum training opportunities

Source: own study.

Work in the Police is very difficult and requires full dedication from officers, because any shortcomings can have an impact and significance for the society and the fate of the policeman himself. It is associated with a very high risk, which is why police officers should be appreciated by their superiors all the time, because this is of great psychological importance to them and motivates them to perform their tasks more effectively. Despite the technological development, the most important capital for every organization is a human being, therefore it is necessary to create a management system that will motivate everyone to work and guarantee that they stay in the given position as long as possible and trigger thinking among officers that they are the most important link in the development of the Police. The key issue in the process of creating such a system is to adapt trainees' expectations to all incentive systems.

Despite the fact that the Police is a public administration body that is responsible for the protection of public security and order, it must have an appropriate standard of human resource management in order to properly implement its tasks. Properly selected trainings allow training of police personnel. Each officer who undergoes appropriate training tailored to his requirements, acquires new skills that help him in getting to work and dealing with all situations encountered in the course of his service.

The analyzes showed what training policy looks like in police structures. All decisions related to the selection of the training offer for individual units are made very prudently and with great precision. Officers are appointed to them who should be included in selected trainings at a given moment. The selection of officers is conducted in great detail, because it involves very large financial outlays for all training for officers. The tasks that the Act imposes on the Police and other ordinances are extremely difficult to perform. Well-trained and motivated officers perform their tasks well, which ensures proper security for citizens. Through their tasks and the efficiency of their performance, the Police build their image in society as a professional and trustworthy citizen institution. 


\section{References:}

Adeniran, A.O., Hamid, M.J., Noor, H.M. (2020). Impact of information technology on strategic management in the banking sector of Iraq. Insights into Regional Development, 2(2), 592-601. https://doi.org/10.9770/IRD.2020.2.2(7)

Bańka, A. (2006). Career capital - conditions, development and adaptation to organizational and structural changes in the labor market [in] Z. Ratajczak, A. Bańka, E. Turska (red.), Contemporary psychology of work and organization, Katowice University of Silesia Publishing House.

Bilan, Y., Mishchuk, H., Roshchyk, I. \& Kmecova I. (2020). Analysis of Intellectual Potential and its Impact on the Social and Economic Development of European Countries. Journal of Competitiveness, 1, 22-38. https://doi.org/10.7441/joc.2020.01.02

Bilan, Y., Mishchuk, H., \& Dzhyhar, T. (2017). Human capital factors and remuneration: analysis of relations, modelling of influence. Business: Theory and Practice, 18, 208 - 214. https://doi.org/10.3846/btp.2017.022

Bombiak, E. (2020). Advances in the implementation of the model of sustainable human resource management: Polish companies` experiences. Entrepreneurship and Sustainability Issues, 7(3), 1667-1687. https://doi.org/10.9770/jesi.2020.7.3(16)

Bramley, P. (2001). Training effectiveness assessment. Kraków: Publishing house ABC.

Domański, S.R. (1993). Human capital and economic growth. Warszawa: Publishing house PWN.

Griffin, R.W. (2007). Fundamentals of organization management. Warszawa: Publishing house PWN.

Jurgilewicz, M. (2017). The role of entities authorized to use or use means of direct coercion and firearms in the protection of public safety and order. Siedlce: Publishing house UPH.

Kostera, M., Kownacki S. (1996). Management of social potential of the organization. Career planning. Warszawa: Publishing house PWN.

Król, H., Ludwiczyński, A. (2007). Human resource Management. Creating the human capital of the organization. Warszawa: Publishing house PWN.

Laužikas, M., Miliūte, A. (2020). Human resource management effects on sustainability of high-tech companies: what Lithuania and South Korea can learn from each other. Insights into Regional Development, 2(2), 562-579. https://doi.org/10.9770/IRD.2020.2.2(5)

Lorek, M. (2017). Motivating in the Polish Police. Rzeszów: Publishing house of the Rzeszów University of Technology.

Mishchuk, H., Bilan, Y., \& Pavlushenko, L. (2016). Knowledge management systems: issues in enterprise human capital management implementation in transition economy. Polish Journal of Management Studies, 14(1), 163-173. https://doi.org10.17512/pjms.2016.14.1.15

Pocztowski A. (2003). Human resource Management. Strategies - processes - methods. Warszawa: Publishing house PWN.

Pocztowski A. (2008). Human resource management. Kraków: Publishing house Antykwa.

Rae L. (1999). Training planning and design. Kraków: Publishing house ABC.

Ścibiorek Z. (2010). Investing in Staff. Toruń: Publishing house Adam Marszałek.

Szałkowski A., Miś A., Piechnik-Kurdziel A. (1996). Introduction to personnel management. Kraków: Publishing house AE.

Tyborowska J. (2006). Personnel Management. A must for human resources departments. Warszawa: Publishing house C. H. Beck.

Zbiegień-Maciąg L. (1996). Personnel marketing, or how to manage an employee in a company. Warszawa: Business Press. 
Marlena LOREK is a professor at the Department of Security Sciences at the Faculty of Management of Rzeszów University of Technology. Author of studies on inter alia management and internal security.

ORCID ID: 0000-0002-6814-8162

Teresa PIECUCH is a professor at the Department of Entrepreneurship, Management and Eco-innovation at the Faculty of Management of the Rzeszów University of Technology. Author of studies on, among others, management and entrepreneurship.

ORCID ID: 0000-0003-2656-662X

Jolanta ITRICH-DRABAREK is a professor at the Institute of Political Sciences of the Faculty of Political Sciences and International Studies of the University of Warsaw. Author of studies on, among others, personnel management in public administration as well as the professional ethics of state officials.

ORCID ID: 0000-0001-7509-3561

Mirosław MINKINA is a professor at the Institute of Social and Security Sciences of the University of Natural Sciences and Humanities in Siedlce. Author of research on, among others special services, state security.

ORCID ID: 0000-0002-2391-314X 